\title{
Evaluation of Indoor Environmental Quality and Health Concerns in a Public Elementary School
}

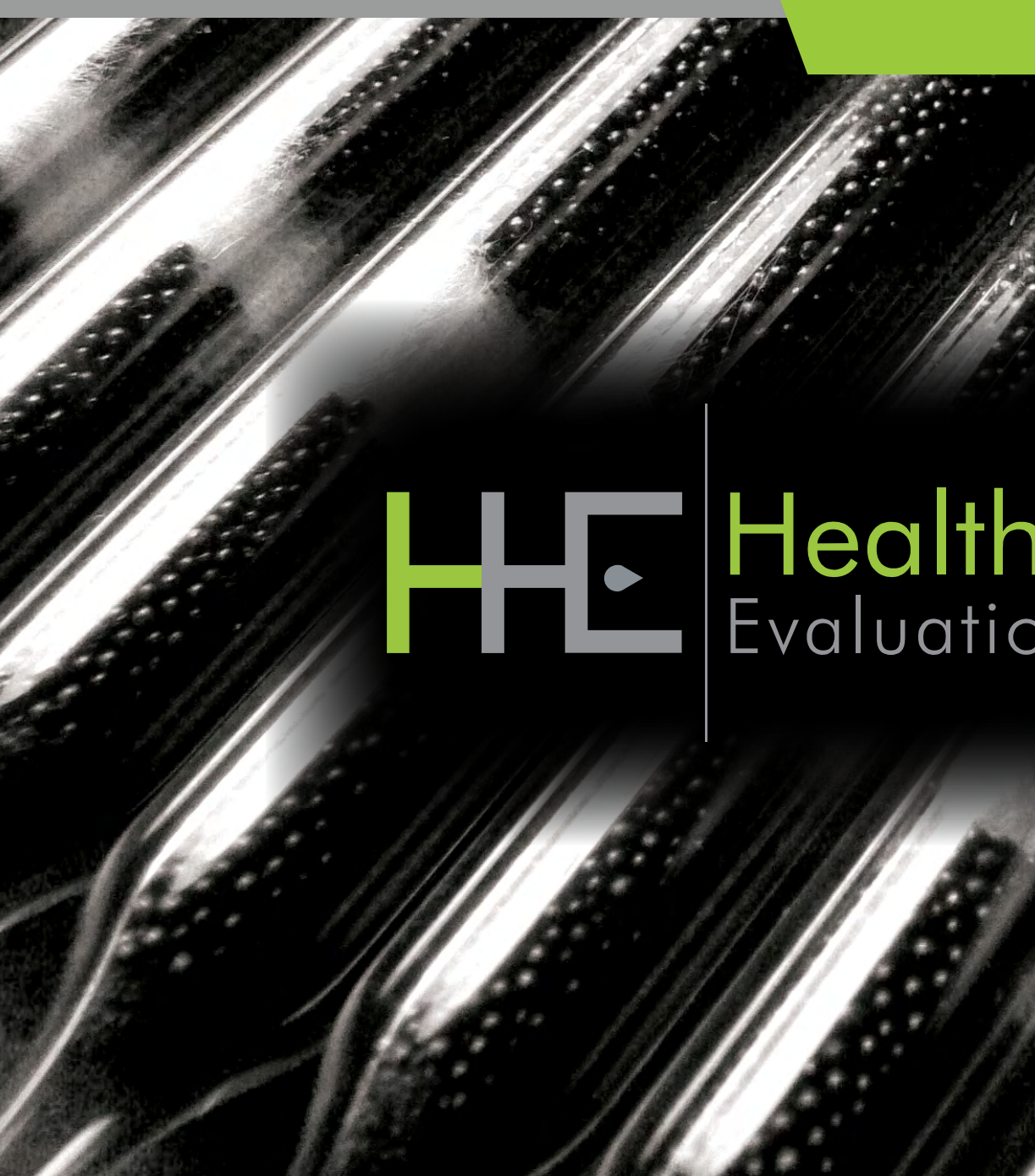

HHE Report No. 2015-0025-3237

June 2015

\section{Elena Page, MD, MPH Gregory Burr, $\mathrm{CIH}$ Leonard Zwack, ScD} Melody Kawamoto, MD, MS

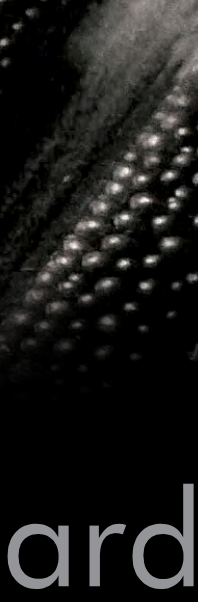
Program 


\section{Contents}

Highlights.

Abbreviations ...................................... iii

Introduction ............................................ 1

Methods.............................................. 1

Results ................................................ 4

Discussion ........................................ 12

Conclusions........................................ 17

Recommendations.......................... 17

Appendix A ....................................... 20

References ........................................ 24

Acknowledgements............................ 29

The employer is required to post a copy of this report for 30 days at or near the workplace(s) of affected employees. The employer must take steps to ensure that the posted report is not altered, defaced, or covered by other material.

The cover photo is a close-up image of sorbent tubes, which are used by the HHE Program to measure airborne exposures. This photo is an artistic representation that may not be related to this Health Hazard Evaluation. Photo by NIOSH. 


\section{Highlights Page}

The Health Hazard Evaluation Program received a union request from an elementary school because some employees had concerns about potential exposure to mold in the school.

\section{What We Did}

- We checked for moisture, water damage, and mold inside the building and in the crawl spaces beneath the building.

- We looked at the ventilation systems.

- We measured carbon dioxide, temperature, and relative humidity.

- We interviewed employees. We asked about their work, medical history, and work-related health concerns.

\section{What We Found}

- We found no moisture, signs of water damage, or mold in the school or crawl spaces, except for three classrooms with minor mold growth that was being fixed.

- We saw no mold on the classroom unit ventilators we checked.

- Some classroom unit ventilators did not work, had incorrectly installed or missing air filters, or were partially or completely blocked.

- Carbon dioxide levels were high in some classrooms. This means that the unit ventilators did not provide enough outdoor air to maintain acceptable ventilation throughout the day.

- Some employees had received inappropriate medical tests.

- Although we did not link employees' symptoms

We evaluated concerns about mold exposure in a school. We saw no widespread mold or water damage. Many symptoms reported by employees have been associated with damp buildings and/or inadequate ventilation but are also common in the general population. We found no evidence that problems such as neuropathy, thrush, and cancer were related to the school. Blood testing for mold and urine testing for mycotoxins should not be done. We recommended stopping environmental sampling and conducting a comprehensive ventilation assessment. and illnesses directly to the school, some nonspecific symptoms are likely related to poor ventilation.

- We found no evidence that health problems such as neuropathy, thrush, and cancer were related to working in the school.

- Some employees might have had health symptoms related to earlier episodes of water damage. 


\section{What the Employer Can Do}

- Hire a licensed professional mechanical engineer to assess the school's ventilation systems.

- Stop environmental sampling for chemical and biological causes for the symptoms discussed in this report.

- Stop blood testing for molds and urine testing for mycotoxins.

- Review the building's preventive maintenance plan with the goal of maintaining a healthy and safe school.

- Encourage employees to report water leaks or water damage to the facilities maintenance.

- Create a system for employees to report building concerns and to receive feedback on how issues were resolved.

\section{What Employees Can Do}

- Report work-related health concerns to school officials.

- See an occupational medicine physician about health problems you think may be related to work.

- Recognize that some symptoms may not have a medical diagnosis.

- Join the indoor environmental quality committee. 


\section{Abbreviations}

$\begin{array}{ll}\text { ANSI } & \text { American National Standards Institute } \\ \mathrm{CO}_{2} & \text { Carbon dioxide } \\ \text { EPA } & \text { Environmental Protection Agency } \\ \text { IEQ } & \text { Indoor environmental quality } \\ \text { IgG } & \text { Immunoglobulin G } \\ \text { IARC } & \text { International Agency for Research on Cancer } \\ \text { NIOSH } & \text { National Institute for Occupational Safety and Health } \\ \text { ppm } & \text { Parts per million } \\ \text { RH } & \text { Relative humidity }\end{array}$




\section{This page left intentionally blank}




\section{Introduction}

The Health Hazard Evaluation Program received a request from a union representing employees at an elementary school because of concerns about exposure to mold in the school building. During our February 2015 site visit we met with elementary school and school district administrators, representatives from the state health department, parent representatives to the district's health and safety committee, the school nurse, and representatives from three school unions.

\section{Background}

In 2014, some elementary school employees went on medical leave reportedly because of illness from mold exposure after receiving results from fungal immunoglobulin $\mathrm{G}$ (IgG) blood tests and urine mycotoxin tests. Knowledge of these results prompted over 20 additional school employees to have their blood tested for IgG to fungi. Some of these employees and their physicians interpreted their blood test results as meaning they had high levels of mold in their bodies. Other employees had recurring upper respiratory and sinus infections and throat and eye irritation that they attributed to their work environment. School administrators had hired consultants in the fall of 2014, including physicians, microbiologists, industrial hygienists, and geologists, to evaluate the indoor environmental quality (IEQ) of the elementary school in response to the ongoing employee concerns about potential mold exposures.

\section{Methods}

Our objectives for this evaluation were to answer the following questions:

1. Does the school have a mold problem or other IEQ problems?

2. Are employees reporting work-related health effects that could be associated with current or past mold exposures or other IEQ issues?

\section{Indoor Environmental Quality Consultant Reports}

We reviewed the IEQ-related consultant reports posted on the school district website before making our site visit (Table 1). All but two reports pertained to evaluating employee comfort, adequate ventilation, mold and fungi sampling, and determining the presence of asbestos-containing materials. One consultant report was of an investigation to determine if groundwater was affecting the lower level of the school. Another consultant report was for radon diagnostic testing at the school. 
Table 1. Summary of environmental assessments at the school

\begin{tabular}{|c|c|c|c|c|}
\hline $\begin{array}{l}\text { Report } \\
\text { date }\end{array}$ & Source & Activities & Methods & Findings \\
\hline $2 / 23 / 15$ & $\begin{array}{l}\text { Industrial } \\
\text { hygiene } \\
\text { consulting } \\
\text { firm \#1 }\end{array}$ & $\begin{array}{l}\text { IEQ assessment } \\
\text { of projects room } \\
\text { and music room }\end{array}$ & $\begin{array}{l}\text { Visual assessment and } \\
\text { thermal imaging camera }\end{array}$ & $\begin{array}{l}\text { No mold growth, no active } \\
\text { moisture intrusion, } \\
\text { acceptable indoor } \\
\text { environmental quality }\end{array}$ \\
\hline 2/5/15 & $\begin{array}{l}\text { Geological } \\
\text { engineering } \\
\text { firm }\end{array}$ & $\begin{array}{l}\text { Hydrogeologic } \\
\text { investigation to } \\
\text { determine if } \\
\text { groundwater was } \\
\text { affecting the } \\
\text { lower level of the } \\
\text { school }\end{array}$ & $\begin{array}{l}\text { Test drilling and well } \\
\text { monitoring in four locations } \\
\text { over } 3 \text { months }\end{array}$ & $\begin{array}{l}\text { No groundwater seepage into } \\
\text { and around the school }\end{array}$ \\
\hline $1 / 28 / 15$ & $\begin{array}{l}\text { Industrial } \\
\text { hygiene } \\
\text { consulting } \\
\text { firm \#2 }\end{array}$ & $\begin{array}{l}\text { IEQ assessment } \\
\text { of rooms } 210 \\
\text { and } 214\end{array}$ & $\begin{array}{l}\text { Temperature, relative } \\
\text { humidity }(\mathrm{RH}) \text {, and } \\
\text { carbon dioxide }\left(\mathrm{CO}_{2}\right) \\
\text { measurements }\end{array}$ & $\begin{array}{l}\text { Comfort indicators outside } \\
\text { ASHRAE guidelines, and } \\
\text { periods of inadequate } \\
\text { ventilation. Peak indoor } \mathrm{CO}_{2} \\
\text { concentrations exceeded } \\
\text { outdoor concentrations by } \\
>700 \text { parts per million (ppm). }\end{array}$ \\
\hline $1 / 20 / 15$ & $\begin{array}{l}\text { Industrial } \\
\text { hygiene } \\
\text { consulting } \\
\text { firm \#1 }\end{array}$ & $\begin{array}{l}\text { Identification and } \\
\text { quantification of } \\
\text { viable mold in } \\
\text { classrooms } \\
13,14 \text {, and } 15\end{array}$ & $\begin{array}{l}\text { Surface sampling for mold } \\
\text { using agar contact plates }\end{array}$ & $\begin{array}{l}\text { Viable mold growth found on } \\
\text { the north walls of rooms } \\
14 \text { and } 15\end{array}$ \\
\hline $12 / 1 / 14$ & $\begin{array}{l}\text { Industrial } \\
\text { hygiene } \\
\text { consulting } \\
\text { firm \#1 }\end{array}$ & $\begin{array}{l}\text { Mold } \\
\text { assessment in } \\
\text { rooms } 4,7,8 \text {, } \\
12,13,14 \text {, and } \\
15\end{array}$ & $\begin{array}{l}\text { Visual assessment and } \\
\text { surface sampling for mold } \\
\text { using tape lift technique }\end{array}$ & $\begin{array}{l}\text { Some visual evidence of } \\
\text { staining from water intrusion, } \\
\text { but no visible evidence of } \\
\text { mold growth }\end{array}$ \\
\hline $11 / 14 / 14$ & $\begin{array}{l}\text { Industrial } \\
\text { hygiene } \\
\text { consulting } \\
\text { firm \#1 }\end{array}$ & $\begin{array}{l}\text { Report on mold } \\
\text { and asbestos. } \\
\text { Initial (October } \\
2014 \text { ) and follow- } \\
\text { up (November } \\
2014 \text { ) surveys } \\
\text { included rooms } \\
5 A, 5 B, 13,14 \text {, } \\
15,114,210 \text {, } \\
211,214,217 \text {, } \\
\text { and } 220\end{array}$ & $\begin{array}{l}\text { Visual assessment and use } \\
\text { of thermal imaging camera } \\
\text { and borescope. Surface } \\
\text { sampling for mold using } \\
\text { tape lift technique and } \\
\text { air sampling for mold. Air } \\
\text { samples were analyzed by } \\
\text { polymerase chain reaction. } \\
\text { Bulk samples were } \\
\text { analyzed for asbestos by } \\
\text { polarized light microscopy. }\end{array}$ & $\begin{array}{l}\text { Some visual evidence of } \\
\text { staining from water intrusion. } \\
\text { Surface and air samples for } \\
\text { mold revealed conditions } \\
\text { similar to those expected to } \\
\text { be found outdoors. } \\
\text { Efflorescence was noted on } \\
\text { some surfaces, but no } \\
\text { asbestos-containing material } \\
\text { was found. }\end{array}$ \\
\hline $8 / 14 / 14$ & $\begin{array}{l}\text { Industrial } \\
\text { hygiene } \\
\text { consulting } \\
\text { firm \#2 }\end{array}$ & $\begin{array}{l}\text { Final report on } \\
\text { the microbial } \\
\text { investigation and } \\
\text { moisture } \\
\text { assessment of } \\
\text { the projects } \\
\text { room in } \\
\text { July } 2014\end{array}$ & $\begin{array}{l}\text { Visual assessment and } \\
\text { thermal imaging camera. } \\
\text { Surface sampling for mold } \\
\text { using tape lift technique. }\end{array}$ & $\begin{array}{l}\text { Visual evidence in the } \\
\text { projects room closet of water- } \\
\text { damaged base molding and } \\
\text { walls, and suspected } \\
\text { microbial growth on the lower } \\
\text { portion of the closet walls. } \\
\text { Report described microbial } \\
\text { surface sample results } \\
\text { consistent with "moderate to } \\
\text { heavy growth." }\end{array}$ \\
\hline $2 / 13 / 02$ & $\begin{array}{l}\text { State health } \\
\text { department }\end{array}$ & $\begin{array}{l}\text { Final report of } \\
\text { radon diagnostic } \\
\text { testing in the } \\
\text { school. }\end{array}$ & $\begin{array}{l}\text { Passive diffusion samplers } \\
\text { placed in } 12 \text { classrooms, } \\
\text { sampling over } 3 \text { days. }\end{array}$ & $\begin{array}{l}\text { Results ranged from } \\
0.1 \text { to } 0.5 \text { picocuries per } \\
\text { liter of air. }\end{array}$ \\
\hline
\end{tabular}




\section{Building Walk-through Survey}

We toured the entire school, including classrooms, multipurpose areas, library, project room, gymnasium, and administrative offices. We also examined areas in the school not readily accessible to teachers and students, such as a mechanical room on a mezzanine adjacent to the gymnasium, three of four crawl spaces beneath the building, and a ground floor equipment storage and workshop area used by the facilities maintenance department. The fourth crawl space was not accessed because deep snow blocked the exterior entrance. We also did not access the roof because of the snow.

We visually assessed the school for potential mold contamination. We also used the following instruments to check for the presence of hidden moisture or water damage:

- A FLIR TG165 imaging infrared thermometer. We used this direct-reading device to identify potential moist or water-damaged areas in surfaces such as walls, floors, and ceilings. It uses infrared thermal imaging technology to react to temperature differences to identify dry and wet materials, even materials that are not readily visible, such as behind drywall or above a suspended ceiling.

- A TRAMEX Moisture Encounter Plus nondestructive moisture meter. This handheld direct-reading device can measure the interior wall moisture levels. We used the moisture meter to confirm if suspected moist areas identified by the infrared thermometer were actually moist.

We measured $\mathrm{CO}_{2}$, temperature, and $\mathrm{RH}$ in classrooms and multipurpose areas over 2 school days with calibrated TSI Q-Trak ${ }^{\text {TM }}$ Indoor Air Quality monitors. We selected classrooms on the basis of their location. For example, we chose first or second floor classrooms and classrooms and teaching areas that were in the oldest and the newer sections of the school. We compared indoor and outdoor $\mathrm{CO}_{2}$ concentrations to determine if indoor occupied spaces were adequately ventilated [ANSI/ASHRAE 2013a]. $\mathrm{CO}_{2}$ is a normal constituent of exhaled breath and can be used as an indicator of whether enough outdoor air is being introduced into an occupied space to maintain odors to an acceptable level. Indoor $\mathrm{CO}_{2}$ concentrations no greater than 700 ppm above outdoor $\mathrm{CO}_{2}$ concentrations will satisfy a substantial majority (about 80\%) of occupants [ANSI/ASHRAE 2013a].

We measured temperature and RH because these characteristics can affect how employees perceive their indoor environment. We compared the temperature and RH levels to American National Standards Institute/ASHRAE (ANSI/ASHRAE) thermal comfort guidelines for winter [ANSI/ASHRAE 2013b]. The ANSI/ASHRAE Standard 55-2013, Thermal Environmental Conditions for Human Occupancy, specifies conditions in which $80 \%$ or more of the occupants would be expected to find the environment thermally acceptable [ANSI/ASHRAE 2013b]. Assuming slow air movement and 50\% RH, the operative temperatures recommended by ANSI/ASHRAE range from $68.5^{\circ} \mathrm{F}$ to $76^{\circ} \mathrm{F}$ in the winter, and from $75^{\circ} \mathrm{F}$ to $80.5^{\circ} \mathrm{F}$ in the summer. The difference between the two is largely due to seasonal clothing selection. ANSI/ ASHRAE also recommends that RH be maintained at or below 65\% [ANSI/ASHRAE 2013b]. Excessive humidity can promote the growth of microorganisms and dust mites. 
We visually inspected the exterior and interior of unit ventilators. We checked if the unit ventilator was operational, the type and condition of the air filters, whether the outdoor air damper was in the opened or closed position, and if furniture or school supplies interfered with the flow of room air through the ventilator.

\section{Employee Interviews and Medical Record Review}

Before the site visit, we reviewed medical records provided by the district for employees who had filed for workers' compensation because of mold exposure. We also reviewed serum IgG test results provided by the district and a document provided by a teacher that described current and past employees' health issues.

We interviewed all available employees in the building in person. Employees who were on medical leave were interviewed by phone. Employees were asked about medical conditions or symptoms they thought were related to the school environment. We took a medical history to identify unrecognized occupational illness. Medical records were requested if employees reported seeing a physician for health issues that they attributed to the school environment. We did not request medical records for health problems we determined were not related to the building such as infertility.

\section{Results}

\section{Environmental Assessment}

\section{Building Walk-through Survey}

The elementary school had 108 staff and about 600 students at the time of our evaluation. The oldest sections of the school were constructed in 1954 and include the library, the gymnasium, a projects room, and two floors of classrooms. Additional single-story wings of classrooms, administrative offices, and multipurpose classrooms were added in 1961, 1990, 1992, 1997, and 2003-2004. The school's exterior was constructed of glass and metal curtain walls or masonry materials. Parts of the building were constructed on a slab; others were over four separate crawl spaces (three with interior access, one with exterior access). The building had a flat membrane roof that had been replaced in 2011. Classrooms had tile floors except for the kindergarten classrooms, which had carpet, area rugs, and tile. The administrative offices had wall-to-wall carpet, and the gymnasium had hardwood flooring.

Most classrooms were cluttered. In some classrooms the airflow into and out of unit ventilators was partially or completely blocked by furniture, books, or teaching supplies.

\section{Mold and Moisture Assessment}

We accessed all classrooms and common areas to look for indicators of mold or moisture. We saw no mold growth in accessible areas. We identified cooler areas on some accessible classroom walls, ceilings, or floors using the FLIR TG165 thermal imaging thermometer. However, a follow-up check of these surfaces with the TRAMEX Moisture Encounter Plus meter determined that these surfaces were not wet or damp. 


\section{Carbon Dioxide, Temperature, and Relative Humidity}

Table 2 summarizes the $\mathrm{CO}_{2}$ concentrations and temperature and $\mathrm{RH}$ levels measured in classrooms and other school areas over 2 days. Figure 1 shows how the $\mathrm{CO}_{2}$ levels varied throughout the school day. We selected room 7 for display in this report because it was representative of the five classrooms where $\mathrm{CO}_{2}$ levels exceeded outdoor levels by at least $700 \mathrm{ppm}$. This means the classroom unit ventilators in these five rooms were not capable of providing enough outdoor air to maintain acceptable ventilation throughout the school day.

The temperatures in 10 of the 12 classrooms that we monitored were below the recommended thermal comfort guidelines for the winter season of $71^{\circ} \mathrm{F}-79^{\circ} \mathrm{F}$, assuming a clothing insulation value of 1.0 (Table 2) [ANSI/ASHRAE 2013b]. Although RH levels were below the ANSI/ ASHRAE guideline of $65 \%$, the RH levels in some classrooms were in the single digits, a situation that occurs during the winter when outdoor RH levels are also in the single digits.

Table 2. Carbon dioxide, temperature and relative humidity measurements in the school

\begin{tabular}{|c|c|c|c|c|}
\hline Date & $\begin{array}{c}\text { Classroom/Area } \\
\text { (students) }\end{array}$ & $\begin{array}{c}\mathrm{CO}_{2} \text { in ppm } \\
\text { (range) }\end{array}$ & $\begin{array}{c}\text { Temperature }{ }^{\circ} \mathrm{F} \\
\text { (range) }\end{array}$ & $\begin{array}{c}\% \mathrm{RH} \\
\text { (range) }\end{array}$ \\
\hline \multirow[t]{6}{*}{$2 / 24 / 15$} & Room 20 (10) & $620-1,300$ & $70-75 \dagger$ & $9.2-14$ \\
\hline & Room 7 (19) & $590-1,600^{*}$ & $71-74$ & $11-16$ \\
\hline & Room 5B (19) & $630-1,500^{*}$ & $75-92 \dagger$ & $1.6-11$ \\
\hline & Room 216 (25) & $490-1,400^{*}$ & 69-73† & $5.7-11$ \\
\hline & Room 114 (20) & $510-1,500^{*}$ & $67-72 \dagger$ & $6.3-13$ \\
\hline & Library† & $570-1,200$ & $71-74$ & $16-19$ \\
\hline \multirow[t]{6}{*}{$2 / 25 / 15$} & Project room $\ddagger$ & $490-1,000$ & 70-73† & $8.6-14$ \\
\hline & Room 211 (22) & $560-2,300^{*}$ & 70-75† & $12-22$ \\
\hline & Room 3 (10) & $420-890$ & 69-74† & $11-15$ \\
\hline & Musicł & $500-1,000$ & $69-72 \dagger$ & $7.5-13$ \\
\hline & Room 16 (10) & $460-900$ & $71-74$ & $9.4-13$ \\
\hline & Tech lab (24) & $490-820$ & $70-77 \dagger$ & $16-21$ \\
\hline
\end{tabular}

${ }^{*}$ The maximum $\mathrm{CO}_{2}$ concentration exceeded the ambient outdoor air concentration by at least 700 $\mathrm{ppm}$. This suggests that the classroom ventilation system(s) was not providing enough outdoor air to maintain acceptable ventilation throughout the school day [ANSI/ASHRAE 2013a].

†Temperatures were not within recommended thermal comfort guidelines for the winter season of $71^{\circ} \mathrm{F}-79^{\circ} \mathrm{F}$, assuming a clothing insulation value of 1.0 [ANSI/ASHRAE 2013b].

$\ddagger$ Occupancy varied throughout the school day because different classes used the room. 


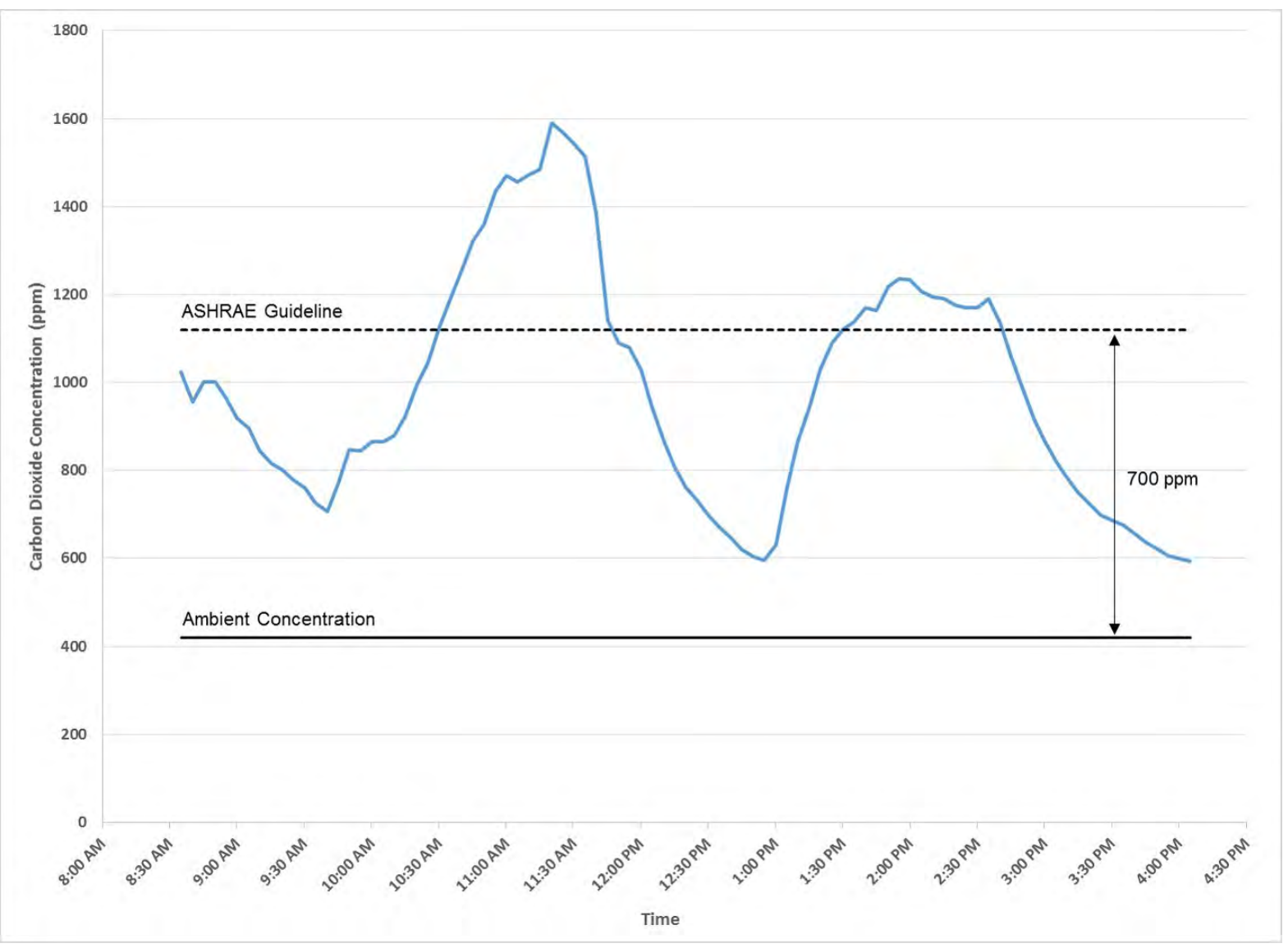

Figure 1. Range of $\mathrm{CO}_{2}$ concentrations in classroom 7 on February 24, 2015.

\section{Ventilation Systems}

Nearly all rooms were ventilated by one or more unit ventilators that were located along the exterior wall. The exceptions were the music room, art room, multipurpose room, library, and administrative offices; each of these areas was connected to a forced-air heating and air-conditioning system. Each unit ventilator was connected to a damper-controlled outdoor air intake that extended from the unit through the exterior curtain wall to the outdoors. All of the unit ventilators provided heat via a perimeter hot-water distribution system, and a few unit ventilators were also capable of providing air-conditioning (Table 3). Some classrooms had window air-conditioners, but none were operating at the time of our evaluation because it was winter.

Because of the different makes, models, and ages of unit ventilators throughout the school, we selected ones to examine on the basis of the manufacturer and/or the model and the date of manufacture (Table 3). The unit ventilator manufacturers included McQuay and Nesbitt, and their manufacturing dates ranged from 1961 to 2003. None of the classroom unit ventilators that we checked had visible evidence of microbial contamination. However, some unit ventilators were not operational as noted in Table 3. 
Table 3. Ventilation systems inspected during the NIOSH evaluation

\begin{tabular}{|c|c|c|c|}
\hline \multirow[t]{2}{*}{ Room/Area } & \multicolumn{2}{|c|}{ Unit ventilator/air handler } & \multirow[t]{2}{*}{ Comments* } \\
\hline & Number & Manufacturer & \\
\hline 4 & 2 & McQuay & $\begin{array}{l}\text { The older unit (based on appearance because there } \\
\text { was no manufacturing date) was not operational. } \\
\text { The newer unit (June 2003) was operational. }\end{array}$ \\
\hline $5 \mathrm{~A}$ & 3 & McQuay & $\begin{array}{l}\text { All three units were capable of heating and } \\
\text { air-conditioning. Two used metal mesh and one used } \\
\text { woven fiberglass air filters. Two units were not } \\
\text { operational. }\end{array}$ \\
\hline $5 B$ & 2 & McQuay & $\begin{array}{l}\text { Both units were capable of heating and } \\
\text { air-conditioning, and both used metal mesh air filters. }\end{array}$ \\
\hline 6 & 2 & McQuay & $\begin{array}{l}\text { Both units were capable of heating and } \\
\text { air-conditioning, and both used metal mesh air filters. }\end{array}$ \\
\hline 23 & 1 & AAF & $\begin{array}{l}\text { Fan speed was set to low. Sections of a pleated air filter } \\
\text { were taped together but the filter was } 1 \text { inch smaller } \\
\text { than the filter frame. }\end{array}$ \\
\hline 112 & 1 & Nesbitt & $\begin{array}{l}\text { Outside air damper was not working (stuck). The } \\
\text { pleated air filter was taped together to fit the } \\
\text { filter frame. Did not have an air filter at the outdoor air } \\
\text { damper. }\end{array}$ \\
\hline 114 & 1 & Nesbitt & $\begin{array}{l}\text { Outside air damper was not working (actuator slipping). } \\
\text { The pleated air filter was taped together to fit the } \\
\text { filter frame. Had a pleated air filter at the outdoor air } \\
\text { damper. }\end{array}$ \\
\hline 214 & 1 & Nesbitt & $\begin{array}{l}\text { Sections of a pleated air filter were taped together to fit } \\
\text { the filter frame. Had a pleated air filter at the outdoor } \\
\text { air damper that was dirty. }\end{array}$ \\
\hline 215 & 1 & Nesbitt & $\begin{array}{l}\text { Sections of a pleated air filter were taped together but } \\
\text { filter was } 1 \text { inch smaller than the filter frame. }\end{array}$ \\
\hline 216 & 1 & Nesbitt & $\begin{array}{l}\text { Outside air damper was not operating properly. } \\
\text { Sections of a pleated air filter were taped together to } \\
\text { try to fit the filter frame. }\end{array}$ \\
\hline $\begin{array}{l}\text { Gym } \\
\text { mezzanine }\end{array}$ & 1 & United Cool Air & $\begin{array}{l}\text { Forced air heating and air-conditioning unit. Minimum } \\
\text { efficiency reporting value } 7 \text { pleated air filters. } \\
\text { The cooling coils had been cleaned in summer } 2014 \text {. }\end{array}$ \\
\hline
\end{tabular}

$\mathrm{NIOSH}=$ National Institute for Occupational Safety and Health

*Unless otherwise noted, the unit ventilators we examined were only capable of heating. 
The unit ventilators we inspected had air filter(s) for the conditioned supply air provided to the classrooms and a separate air filter for the air provided through the outdoor air damper. The types of air filters for the conditioned supply air were a metal mesh, a 1-inch thick woven fiberglass panel, or a pleated air filter. The pleated air filters had a minimum efficiency reporting value of 7; no information was available for the metal mesh or fiberglass panel filter styles. During our inspections we noted it was difficult to remove and replace the air filter at the outdoor air damper because of the unit ventilator design. The outdoor air damper filter was missing on one unit ventilator, and on another unit ventilator the filter appeared dirty and probably needed to be replaced.

According to the school's facilities maintenance supervisor, the air filters (with the possible exception of the metal mesh filters that can be rinsed and reused) were changed every 3 months by an outside contractor. The woven fiberglass panel and pleated air filters we checked appeared clean, but none were correctly sized for the filter opening in the unit ventilator, and in some instances filter pieces had been cut and taped together to try to fit the filter opening (Figure 2).

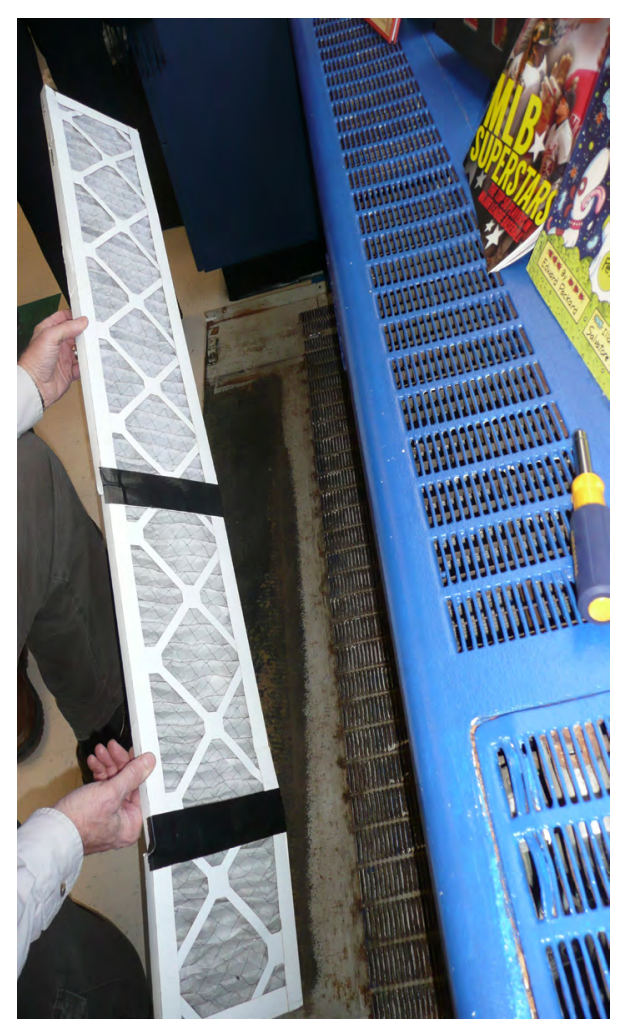

Figure 2. Photo of a pleated panel air filter that was taped together to fit a metal filter frame in a classroom unit ventilator. Photo by NIOSH. 
Table 4 summarizes our visual inspections of three of the four crawlspaces beneath the school. All appeared dry, uncluttered, and with no visible signs of water infiltration. On March 3, 2015, a consultant visually inspected the fourth crawlspace to determine if groundwater or surface water entry was a chronic problem. They found the crawlspace had an uncovered earth floor with visible signs of past water entry. Some suspected mold growth was observed on pipe sleeve insulation, but no pathways connecting the crawlspace and the occupied areas of the school were noted. The consultant recommended installing a vapor barrier in the crawlspace and reconfiguring the roof drains to carry storm water runoff away from the building.

Table 4. Crawlspaces inspected during NIOSH evaluation

\begin{tabular}{ll}
\hline Location & \multicolumn{1}{c}{ Comments } \\
\hline $\begin{array}{l}\text { Crawlspace under } \\
\text { 1954 section }\end{array}$ & $\begin{array}{l}\text { Approximately 4 feet high. The crawlspace had an uncovered earth } \\
\text { floor with no vapor barrier. We did not see any visible water or moisture } \\
\text { or detect a musty odor. Water and sewer pipes and electrical utilities } \\
\text { ran throughout the space. }\end{array}$ \\
$\begin{array}{l}\text { Crawlspace adjacent to } \\
\text { maintenance shop }\end{array}$ & $\begin{array}{l}\text { Approximately } 5 \text { feet high. The crawlspace had a crushed gravel floor } \\
\text { that appeared dry and in very good condition. We did not see visible } \\
\text { water or moisture or detect a musty odor. Some items were stored in } \\
\text { the space, but overall the space was not cluttered. }\end{array}$ \\
$\begin{array}{l}\text { Crawlspace under } \\
\text { kindergarten rooms }\end{array}$ & $\begin{array}{l}\text { Approximately 4 feet high. The crawlspace had a crushed gravel floor } \\
\text { that appeared dry and in very good condition. We saw no water or } \\
\text { moisture nor detected a musty odor. }\end{array}$ \\
\hline
\end{tabular}

The forced-air heating, ventilating, and air-conditioning system supplying the gymnasium and several small offices and storage areas adjacent to the gym was located in a mezzaninelevel mechanical room. This air handler used $20 \times 25 \times 2$-inch thick pleated air filters (no minimum efficiency reporting value information was available). The installed filters were 1 inch too narrow to properly fit within the air handler's metal filter frame.

\section{Medical Assessment}

\section{Serum IgG to Fungi}

Concerns about mold growth in the school were triggered by the attribution of a serious medical condition in an employee to fungal exposure in school, on the basis of serum IgG tests for molds and urine tests for mycotoxins. Having this information prompted over 20 employees to have similar IgG testing performed. At least one employee reported they were saving money to have urine mycotoxin testing done. The laboratory reports from the IgG test that we reviewed stated, "Results for this test are for investigational purposes only by the assay's manufacturer. The performance characteristics of this product have not been established. Results should not be used as a diagnostic procedure without confirmation of the diagnosis by another medically established diagnostic product or procedure." 


\section{Employee Interviews and Medical Records Review}

We interviewed 100 of 108 employees; 11 were male. The length of employment ranged from less than 1 year to 32 years. Of the 100 interviewed employees, 47 reported no symptoms or medical conditions related to the school environment, and 53 reported symptoms or medical conditions that they felt were or might be related to the school environment. The most common reported symptoms thought to be related to the school environment were headache (22), sinus infections or congestion (21), runny or stuffy nose (10), and eye irritation (6). Symptoms reported by fewer than five people included fatigue, sore or dry throat, memory problems, post-nasal drip, frequent upper respiratory infections, skin problems, dizziness, cough, and shortness of breath.

We asked interviewed employees if they had ever had asthma, hay fever, or eczema so we could estimate the prevalence of atopy (the predisposition toward allergic diseases). Over half of the interviewed employees reported at least one of these conditions, suggesting they are atopic. Six employees reported current asthma (including three diagnosed since beginning work at the school), but none reported increased inhaler use at school or worsening of symptoms at school. One of these six employees reported that she needed to use her inhaler at the school several years ago, but not in the past 2-3 years. Medical records were reviewed for the three employees diagnosed with asthma since beginning work at the school to look for documentation of a relationship to work. One employee's medical records, going back several years, did not mention asthma at all. The other two employees' records documented a diagnosis of asthma, but did not state how the diagnosis was reached nor make any reference to an association with the school. The school nurse reported that no students in the past 5 years had required regular inhaler use, and that she had not noted an increase in respiratory illnesses among students during her over 20-year tenure at the school.

One employee reported fevers occurring daily at school, improving when leaving school, and completely resolving by the beginning of the next day. The fever was accompanied by upper respiratory symptoms and chronic cough. The employee had not received diagnostic testing but reported being on steroids since before Christmas (over 2 months). We examined the employee's medical records because we were concerned about possible hypersensitivity pneumonitis. The medical records documented no report of fever, but did document post-nasal drip responsible for the cough. Additionally, this employee had been prescribed inhaled nasal steroids, not oral systemic steroids. We found no evidence of hypersensitivity pneumonitis.

Two employees reported having fungus cultured from their sinuses. Medical records were reviewed for both employees. It is unclear why fungal cultures were ordered, other than the patient reporting exposure to mold at the school. Both underwent nasal endoscopy (a visual examination of the interior of the nose with an endoscope) at about the time the culture was collected, had computed axial tomography (also called CT or CAT scans) of the sinuses, and had screening allergy skin testing with an atopy panel consisting of trees, grasses, molds, epidermals (like cat hair), inhalants (like dust mite), and positive and negative controls. Allergy testing was completely negative for one patient; the other reacted to mugwort only. However, both patients were diagnosed with allergic rhinitis. Their CT scans showed no evidence of sinusitis. Endoscopy showed swelling and mucus in the nose and sinuses. 
Both patients had a deviated nasal septum, which often leads to sinus problems. One had Aspergillus fumigatus, and one had Curvularia growth on the fungal culture. It is not unusual to have these types of common fungus in the sinuses.

We reviewed records for three other employees in addition to the medical records reviewed for the six employees noted above. None documented a work-related condition.

Several employees reported medical issues, for example, neuropathy; difficulty walking; food allergies; abnormal uterine bleeding; preterm birth; eosinophilic esophagitis (allergic inflammation of the esophagus); thrush (a type of fungal disease); leg pain and weakness; hormonal imbalance; autism, birthmarks, and allergies in their children; bleeding during pregnancy; and hypothyroidism and hyperthyroidism. Several employees expressed concern that cancer diagnosed among employees, primarily breast cancer, was related to the school environment. A teacher provided a list of employees with various cancers, including eight breast, one endometrial, and one prostate.

Four employees mentioned the smell of machine exhaust in their classroom when facilities maintenance personnel started or idled gas or diesel-powered machinery near the building. The facilities maintenance offices and storage area were located on the ground floor beneath the kindergarten wing.

Several employees noted increased stress levels for several years. They attributed this to a variety of policies and procedures, such as changes in tenure, teacher evaluations, and the Common Core State Standards Initiative requirements, as well as an increase in the number of mandatory meetings. Another reported stressor was parents' use of social media to criticize teachers, especially when parents rely on the word of a child without learning about the context from the teacher. Several employees also reported that they had not noticed symptoms until other employees started talking about the perceived mold problems in the school, or that they had not attributed their symptoms to the school until other employees started talking about the mold problems.

\section{Medical Consultant Report}

Before our evaluation, the school district had consulted an occupational medicine physician who specialized in mold-related illness. In addition to touring the school, this physician distributed an IEQ medical screening survey to employees and provided a written report of his findings. Sixty-four employees (51 teachers or teacher's aides and 13 other staff) responded, for a participation rate of 59\%. Teachers and aides $(60 \%)$ reported more workrelated symptoms than other staff (23\%). Participants who reported seeing leaks, dampness, mold, and mildew at the school reported more upper and lower airway, skin, eye, and central nervous system symptoms than those who did not report seeing these things. Two teachers reported new-onset asthma, and two reported worsening of asthma. No participants reported invasive fungal infections or hypersensitivity pneumonitis. The occupational medicine physician concluded that some participants' symptoms could be related to water damage in the building but that causation for any individual could not be determined. 


\section{Discussion}

Use of inappropriate and unvalidated medical testing triggered and sustained many of the concerns at this school. Some of the test reports noted that they were not to be used for diagnosis because they were for investigational use only. Apparently, many of the physicians who ordered the tests did not discuss this limitation with the employees they tested. Some test reports noted that the laboratory was certified. The Centers for Medicare and Medicaid Services' Clinical Laboratory Improvement Act certification (also referred to as CLIA) indicates that a laboratory meets a set of basic quality and analytic standards, such as the accuracy and reliability of test results. It does not address the clinical validity of a test (i.e., the accuracy with which the test identifies, measures, or predicts the presence or absence of a clinical condition in a patient). The Food and Drug Administration clearance or approval of a test provides assurance that the test has adequate analytical and clinical validation and that it is safe and effective. The tests used were not cleared or approved by the Food and Drug Administration.

Serum IgG tests are not useful in evaluating building-related illness or fungal exposure because of the ubiquitous nature of many fungi and the lack of specificity of fungal antigens [Trout et al. 2004; Agence de la santé et des services sociaux de Montréal 2015]. Mycotoxins are metabolites of some fungi that can cause illness in humans and animals, primarily after ingestion of contaminated foods. Because low levels of mycotoxins can be found in many foods, mycotoxins are found in the urine of healthy persons [Ahn et al. 2010; Duarte et al. 2011]. Mycotoxin levels that predict disease have not been established. Urine mycotoxin tests are not approved by the Food and Drug Administration for accuracy or for clinical use [Kawamoto and Page 2015].

No airborne exposure standards specific to the nonindustrial indoor environment exist. Likewise, no exposure guidelines for mold (or other microbes) in air exist, so it is not possible to distinguish between "safe" and "unsafe" levels of exposure. Therefore, measuring indoor environmental contaminants, such as mold or volatile organic compounds, has seldom proved helpful in determining the cause of symptoms. However, we often measure ventilation and comfort indicators, such as $\mathrm{CO}_{2}$, temperature, and $\mathrm{RH}$, to provide information relative to the functioning and control of heating, ventilating, and air-conditioning systems. For this reason, we recommend stopping sampling for mold and redirecting resources toward improving the ventilation systems.

One of the most common deficiencies we have found over many years of health hazard evaluations in nonindustrial indoor environments is the improper operation and maintenance of ventilation systems, and this is the case in this school. An analysis of the published scientific literature showed that nonspecific symptoms such as headache, fatigue, and mucous membrane irritation increase as ventilation rates decrease [Fisk et al. 2009]. Studies in schools and office buildings have found a decrease in illness-related absences with increased ventilation rates [Milton et al. 2000; Shendell et al. 2004; Mendell et al. 2013]. Thus, improving heating, ventilation, and air conditioning operation and maintenance and increasing ventilation rates can improve symptoms without ever identifying any specific cause-effect relationships. We believe similar benefits would occur if ventilation is improved at this school. 
The maximum $\mathrm{CO}_{2}$ concentration exceeded the ambient outdoor $\mathrm{CO}_{2}$ concentration by at least $700 \mathrm{ppm}$ in several classrooms, indicating inadequate ventilation. In addition, temperatures in most classrooms that we checked were not within the ANSI/ASHRAE recommended thermal comfort guidelines for the winter season of $71^{\circ} \mathrm{F}-79^{\circ} \mathrm{F}$. Although the RH levels were within the ANSI/ASHRAE guidelines, the levels were below $20 \%$, not uncommon in winter when heating is needed. Low RH can cause dry skin and drying of the eyes and mucous membranes. Some employees reported these symptoms. In addition to affecting ventilation, the abundance of paper could generate and accumulate dust, which can be irritating to skin and mucous membranes. The clutter may also hinder housekeeping.

Exposure to microbes is not unique to the indoor environment. No environment, indoors or out, is completely free from microbes, not even a surgical operating room. Microbes present in indoor air that are relevant to health include pollen and plant spores coming from outdoors; bacteria, fungi, algae and protozoa from both indoors and outdoors; and microbes and allergens spread from person to person, and from person to environment (including pet dander) [WHO 2009]. Dampness and inadequate ventilation lead to the growth of microbes, and degrade building materials [WHO 2009]. Many buildings have episodes of water or moisture intrusion. The key to preventing microbial growth is to identify the source of moisture and to eliminate it [NIOSH 2012]. Moisture intrusion, along with nutrient sources such as building materials or furnishings, allows mold and other microbes to grow indoors, so it is important to keep the building interior and furnishings dry [NIOSH 2012]. Remediation of microbial contamination may improve IEQ conditions even though a specific cause-effect relationship is not determined. NIOSH investigators routinely recommend remediating observed microbial contamination and correcting situations that are favorable for microbial growth and bioaerosol dissemination [NIOSH 2012].

The type and severity of symptoms related to mold exposure in the indoor environment depends on the extent of the mold present, the extent of the individual's exposure, and the susceptibility of the individual (for example, whether he or she has preexisting allergies or asthma). Sufficient epidemiological evidence indicates an association between occupancy in damp buildings and upper and lower respiratory tract symptoms (including cough, wheeze, and shortness of breath), respiratory infections, asthma, exacerbation of asthma, bronchitis, allergic rhinitis, and eczema [WHO 2009; Mendell et al. 2011]. Clinical evidence shows that exposure to mold and other microbial agents in damp buildings is associated with hypersensitivity pneumonitis [WHO 2009]. The specific agents (i.e., mold, bacteria, or other agents present in damp buildings) causing health problems have not been identified [WHO 2009; Mendell et al. 2011]. People with weakened immune systems (those with diabetes, on chronic systemic steroid therapy, with cancer, or acquired immune deficiency syndrome, among other things) may be more vulnerable to infections by molds. While some individuals may get infected after indoor exposure, it is not from water damage. Certain molds that are found everywhere may cause infection in a suitable susceptible host. Such infections are called "opportunistic." However, no studies link these opportunistic infections to mold in the indoor environment [WHO 2009]. Healthy individuals are usually not vulnerable to infections from airborne mold exposure, and no school employees had an opportunistic fungal infection. 
Some of the symptoms employees reported, such as runny or stuffy nose, cough, shortness of breath, eye irritation, and sore throat, could be related to past incidents of water intrusion with resultant microbial growth. At the time of our evaluation, three rooms were under remediation for small areas of mold growth and, thus, unoccupied. Although isolated areas of fungal growth were mentioned in two consultants' reports and could be related to symptoms, the lack of adequate ventilation can also result in these nonspecific symptoms. During our evaluation ventilation deficiencies were almost ubiquitous throughout the school, while past water damage was isolated and limited and we did not see visible mold growth. Therefore, poor ventilation would be more likely to cause symptoms than water damage and mold growth. Drying of the eyes and mucous membranes can be related to the very low humidity environment. In addition, the general stressors of teaching that were reported by some teachers can lead to symptoms as well. However, because of the nonspecific nature of these symptoms (meaning they can be caused by many things), and their commonality in the general population, a link to any particular exposure at the school cannot be made with certainty.

Of the general population, $86 \%-95 \%$ have one or more common symptoms during any given 2- to 4-week period, and the average adult reports a minimum of one symptom every 4-6 days [Barsky and Borus 1995]. Table 5 lists the general population prevalences of many of the symptoms reported by school employees. Women, who comprised the majority of the school's employees, were more likely to report symptoms in all of the studies listed in Table 5. In addition, the average adult has two to three upper respiratory infections per year [Benninger et al. 2003]. According to the National Health Interview Survey, $12 \%$ of U.S. adults reported physician-diagnosed sinusitis in 2012 [CDC 2014]. Women were more likely to be diagnosed with sinusitis (15\% compared to $9 \%$ in men) [CDC 2014]. 
Table 5. General population prevalence of symptoms similar to those reported by school employees

\begin{tabular}{|c|c|c|c|}
\hline & \multicolumn{3}{|c|}{ Population } \\
\hline & $\begin{array}{l}\text { Clustered random sample of } \\
\text { households Australia }\end{array}$ & $\begin{array}{l}\text { General medical } \\
\text { practices in the } \\
\text { United Kingdom }\end{array}$ & $\begin{array}{l}\text { Representative sample of } \\
\text { general population of } \\
\text { New Zealand }\end{array}$ \\
\hline Participants & $n=3,016^{*}$ & $\mathrm{n}=2,474 \dagger$ & $\mathrm{n}=1,000 \ddagger$ \\
\hline Time frame & 14 days & 14 days & 7 days \\
\hline $\begin{array}{l}\text { Number of } \\
\text { symptoms } \\
\text { asked about }\end{array}$ & 12 & 25 & 46 \\
\hline $\begin{array}{l}\text { Percent } \\
\text { reporting } \\
\text { at least } \\
\text { one symptom }\end{array}$ & 80 & $>75$ & 89 \\
\hline $\begin{array}{l}\text { Number of } \\
\text { symptoms } \\
\text { reported, } \\
\text { mean (range) }\end{array}$ & Not reported & $3.6(0-22)$ & $5(0-36)$ \\
\hline $\begin{array}{l}\text { Symptoms } \\
\text { similar to } \\
\text { those } \\
\text { reported at } \\
\text { this school } \\
\text { (\% of school } \\
\text { employees) }\end{array}$ & $\begin{array}{c}\text { Stuffy nose }(46) \\
\text { Headache }(33) \\
\text { Unusually tired }(30) \\
\text { Cough }(26) \\
\text { Dry, itchy, or irritated eyes (25) } \\
\text { Dry or sore throat (22) } \\
\text { Skin rash (12) }\end{array}$ & $\begin{array}{l}\text { Tired/run down (41) } \\
\text { Headache (39) } \\
\text { Sore throat (19) } \\
\text { Cough (18) }\end{array}$ & $\begin{array}{c}\text { Fatigue (36) } \\
\text { Headache (35) } \\
\text { Congested or runny nose (34) } \\
\text { Cough (28) }\end{array}$ \\
\hline
\end{tabular}

${ }^{*}$ Reference: Heyworth and McCaul 2001

†Reference: McAteer et al. 2011

†Reference: Petrie et al. 2014

The U.S. Environmental Protection Agency (EPA) conducted a systematic survey of 100 randomly selected office buildings without known IEQ complaints in the United States to develop baseline data about U.S. office buildings [Brightman et al. 2008]. NIOSH conducted a similar study of 80 buildings with IEQ complaints [Malkin et al. 1996]. Occupants in both studies reported work-related symptoms. The rank order of symptoms was the same, but rates were significantly higher in the buildings with IEQ complaints. The most common workrelated symptoms reported in both studies were dry, itching, or irritated eyes; unusual tiredness or fatigue; headache; tension or irritability; pain in back, neck, and shoulders; stuffy or runny nose, or sinus congestion; sneezing; sore or dry throat; and difficulty remembering things or concentrating. Of the employees in the randomly selected buildings, $45 \%$ reported at least one work-related symptom. These common symptoms in the general population and in buildings are also among the most common symptoms reported by this school's employees.

Six employees reported current asthma. In 2012, $8 \%$ of U.S. adults reported having physician diagnosed asthma [CDC 2014]. Women are more likely to have asthma (10\% compared to $6 \%$ of men) [CDC 2014]. While development of asthma and exacerbation of asthma are associated with occupancy in damp buildings, this does not appear to be the case at this school. This conclusion is based on the lack of regular inhaler use among students, the lack of a pattern of increased employee inhaler use or asthma attacks while at the school, and the 
lack of documentation in employees' medical records supporting diagnoses of new onset or worsening asthma.

Over half of the interviewed employees reported asthma, hay fever, or eczema, suggesting they are atopic. Atopic individuals are at increased risk of developing allergy to certain substances, among them being "typical" allergens like grasses, pollen, cats, dogs, and dust mites. In addition to allergens present in the school from the intrusion of outdoor air, or their proliferation on building materials, some allergens can be carried in on employees, students, and visitors. The most common of these are cat and dog allergens, which can be an unrecognized source of allergic upper and lower respiratory and skin symptoms among employees and students.

Two employees reported fungal growth in their sinuses. Allergic fungal rhinosinusitis accounts for up to $10 \%$ of chronic rhinosinusitis cases [Hamilos 2010]. Rhinosinusitis is not an infection, but rather a local hypersensitivity reaction to fungal presence, in stark contrast to invasive fungal sinusitis that occurs mainly in immune compromised people [Hamilos 2010]. Diagnostic criteria for allergic fungal sinusitis include (1) chronic rhinosinusitis (almost always associated with nasal polyps), (2) allergic or eosinophilic mucin containing noninvasive fungal hyphae in at least one sinus, (3) lack of a competent immune system, and (4) fungal allergy documented by allergy tests, usually to multiple fungi. Characteristic findings of allergic fungal sinusitis on sinus CT are opacified sinuses with foci of increased density. A fungus ball is merely the noninvasive sloughing of mucus and fungus with no immune response [Hamilos 2010]. Neither of the employees with fungal cultures taken from their sinuses met the criteria for allergic fungal rhinosinusitis, had invasive fungal sinusitis, or had a fungus ball. The fungi found in their sinuses are likely part of their microbiome (microorganisms that share the body space) and not indicative of infection or disease.

All animals, including humans, have microorganisms (including bacteria and fungi), called a microbiome, that live on and in the skin, mucous membranes, and gastrointestinal tract. The goal of the National Institutes of Health Human Microbiome Project is identifying and characterizing the microorganisms found in humans. Investigators took 4,788 specimens from 242 healthy adults to characterize this microbiome [The Human Microbiome Project Consortium 2012]. Samples were collected from 18 sites in women and 15 in men, including the nose. Each site had a broad diversity of microbes among these healthy subjects. In a different study, the sinus microbiome of 30 individuals with chronic rhinosinusitis was similar to that of 12 healthy controls, with cases having 132 fungal species and controls having 106 species [Aurora et al. 2013]. A similar study collected specimens from the sinuses of 23 chronic rhinosinusitis patients and 11 controls and found that fungi were ubiquitous, with 207 fungal genera detected [Cleland et al. 2014].

Many medical issues mentioned by interviewed employees, such as neuropathy, difficulty walking, food allergies, leg pain and weakness, and hormonal imbalance, among others, were unrelated to each other or to the school environment. We determined that the breast, endometrial, and prostate cancers were not related to the school environment. A discussion of cancer and cancer clusters as it applies to this school is in Appendix A. 
Our finding that some school employees began noticing symptoms after becoming aware that their coworkers were talking about them is an example of heightened awareness. Such heightened awareness might lead individuals to notice symptoms they might otherwise overlook. When this happens at work, employees often attribute their symptoms to the work environment. Care must be taken when attributing common symptoms to particular exposures because the association is as likely to be coincidental as to be causal. Symptoms are influenced by cognitive (thought) processes [Bogaerts et al. 2010]. Symptoms have been demonstrated to be more common when pollution or health threats are perceived, as at this school [Watson and Pennebaker 1989; Williams and Lees-Haley 1993], and can be affected by fears, emotional triggers, and litigation [Lees-Haley and Brown 1992].

The building's ventilation systems would not be effective in keeping outdoor contaminants from engine exhaust out of the classrooms. Thus, engine exhaust can enter classrooms from outside and, as a result, could contribute to the some symptoms reported by teachers in affected classrooms. Gasoline and diesel exhaust are irritating to the upper and lower respiratory tracts and have odors that can be offensive to some people. In addition, diesel exhaust can cause lung cancer [International Agency for Research on Cancer 2012].

\section{Conclusions}

We did not see evidence of a current mold problem in the school during our evaluation. However, we identified several correctable problems at the school, in particular, the inadequate ventilation in classrooms. Many of the symptoms employees reported, such as sinus problems and headaches, have been associated with damp buildings or inadequate ventilation but are common in the general population. We found no evidence that the health problems reported by some staff, such as neuropathy, thrush, and cancer, among other things, were related to working in the school. The lack of a ready explanation for all symptoms has led some employees to seek answers from unvalidated medical tests.

\section{Recommendations}

On the basis of our findings, we recommend the actions listed below to create a more healthful workplace. We encourage the school to use their newly formed labor-managementparent health and safety committee to discuss the recommendations in this report and develop an action plan. Those involved in the work can best set priorities and assess the feasibility of our recommendations for the specific situation at the school.

Our recommendations are based on the hierarchy of controls approach. This approach groups actions by their likely effectiveness in reducing or removing hazards. In most cases, the preferred approach is to eliminate hazardous materials or processes and install engineering controls to reduce exposure or shield employees. Until such controls are in place, or if they are not effective or feasible, administrative measures and/or personal protective equipment may be needed. 


\section{Engineering Controls}

Engineering controls reduce exposures to employees by removing the hazard from the process or placing a barrier between the hazard and the employee. Engineering controls are very effective at protecting employees without placing primary responsibility of implementation on the employee.

1. Make renovation of the ventilation systems a top priority. Conduct a comprehensive assessment of the school's ventilation systems in consultation with a licensed professional mechanical engineer who has experience in the design of heating, ventilating, and air-conditioning systems for educational environments.

\section{Administrative Controls}

Administrative controls are management-dictated work practices and policies to reduce or prevent exposures to workplace hazards. The effectiveness of administrative changes in work practices for controlling workplace hazards is dependent on management commitment and employee acceptance. Regular monitoring and reinforcement is necessary to ensure that control policies and procedures are not circumvented in the name of convenience or production.

1. Stop environmental sampling for chemical and biological agents to identify a cause for nonspecific symptoms among faculty, staff, and students.

2. Stop IgG blood testing for molds and urine testing for mycotoxin because they are not useful for assessing exposures or making diagnoses.

3. Implement an IEQ management plan for the school district. Select an IEQ manager or administrator with clearly defined responsibilities, authority, and resources. This individual should have a good understanding of the building's structure and function and should be able to effectively communicate with occupants. This proactive approach can help prevent IEQ problems from occurring. Although comprehensive regulatory standards specific to IEQ have not been established, guidelines have been developed by organizations such as ASHRAE, NIOSH, and the EPA. The EPA has several publications on IEQ, including the IAQ Tools for Schools Action Kit at http:// www.epa.gov/iaq/schools/toolkit.html. The Tools for Schools document discusses IEQ in some detail and includes information on common problems, investigative techniques, and solutions to specific problems. Additional resources include the EPA Healthy School Environments Assessment Tool, available at http://www.epa.gov/ schools/, which helps school districts establish and manage comprehensive school facility self-assessment programs. It contains an environmental health and safety checklist and is designed to be easily customized to reflect state and local requirements and policies. The basic elements of a good IEQ plan include the following:

$\circ$ Properly operating and maintaining the heating, ventilating, and air-conditioning equipment, including accommodating staff who work during hours when the air handling system(s) is routinely cycled off, to ensure that adequate ventilation is provided 
O Overseeing the activities of occupants and contractors that affect IEQ (e.g., housekeeping, pest control, maintenance, food preparation)

$\circ$ Maintaining and ensuring effective and timely communication with occupants regarding IEQ

- Educating building occupants and contractors about their responsibilities in relation to IEQ

- Proactively identifying and managing projects that may affect IEQ (e.g., redecoration, renovation, relocation of personnel)

- Designating a school employee representative who can speak for the teachers and other employees and can assist with communication

Information on selecting IEQ consultants is available from the American Industrial Hygiene Association Guidelines for Selecting an Indoor Air Quality Consultant available at https://www.aiha.org/about-aiha/Press/ConsumerBrochures/ Guidelines $\% 20$ for $\% 20$ Selecting $\% 20$ An $\% 20$ Indoor $\% 20$ Air $\% 20$ Quality $\% 20$ Consultant.pdf.

4. Ask employees to report signs of moisture intrusion to the facilities maintenance staff. The facilities maintenance department should establish a system for responding to requests and notifying the requestor what is being done and when the work is complete.

5. Encourage employees with health concerns to seek evaluation and care from a physician who is residency trained and board certified in occupational medicine and is familiar with the types of exposures employees might have had and their health effects. Occupational medicine physicians can be found through a variety of sources, including the Association of Occupational and Environmental Clinics, at http://www.aoec.org/, and the American College of Occupational and Environmental Medicine, at http://www. acoem.org/. It may be useful to provide the physician with a copy of this report.

6. Work with employee associations to inform employees about the limitations and potential risks of unvalidated medical tests and treatments. Refrain from participating in unvalidated medical testing and treatments without full knowledge and informed consent of risks and benefits. Consultation with staff from a university occupational and environmental medicine clinic is recommended.

7. Implement a formal system for reporting building concerns to the principal or the facilities maintenance manager. This system can be paper or electronic and should include a mechanism to let staff know when and how the problem is fixed. 


\section{Appendix A: Cancer and Cancer Clusters}

\section{Cancer}

Cancer is a group of different diseases that share the same feature of uncontrolled growth and spread of abnormal cells. Each different type of cancer may have its own set of causes. Cancer is common in the United States. In the United States, one in two men and one in three women will develop cancer over the course of their lifetimes. This does not include basal or squamous cell skin cancers, which are very common (more than 3 million diagnosed annually), or any in-situ carcinomas other than bladder. If these were included, rates would be even higher. One of every four deaths in the United States is from cancer. Among adults, cancer occurs more frequently with increasing age. Cancer cases may appear to occur with alarming frequency even when the number of cases is not more than would be expected in the general population because cancer is common, the population is aging, and more people are surviving cancer. This perception is especially common among a small group of people who have something in common with the cases, such as working in the same building.

Many factors play a role in the development of cancer. The importance of these factors varies for different types of cancer. Most cancers are caused by a combination of several factors. Some of the factors include (1) personal characteristics such as age, sex, and race; (2) family history of cancer; (3) diet; (4) personal habits such as cigarette smoking and alcohol consumption; (5) the presence of certain medical conditions; (6) exposure to cancer-causing agents in the environment; and (7) exposure to cancer-causing agents in the workplace. In many cases, these factors may act together or in sequence to cause cancer. Although some causes of various types of cancer are known, we do not know everything about the causes of cancer. One important point to note is that the absence of a risk factor does not mean there is no risk for developing cancer. For example, employees often say to us that they got breast cancer despite having no family history of breast cancer, so it must be due to their work. In fact, while having a first-degree relative with breast cancer increases one's risk of developing breast cancer, most people who get breast cancer do not have a family history of it.

\section{Breast Cancer}

Breast cancer is the most common cancer in women in the United States. An estimated 231,840 cases of invasive breast cancer were diagnosed in women in the United States in 2014, not including 60,290 cases of carcinoma in situ [American Cancer Society 2015b]. One in eight women in the United States will develop breast cancer in their lifetime. Well-established breast cancer risk factors include family history of breast cancer, biopsy-confirmed atypical hyperplasia, early menarche (first menstrual period), late menopause, not having children or having the first child after age 30, overweight or obesity (especially after menopause), never breastfeeding a child, low physical activity levels, and higher levels of education and socioeconomic status [Weiderpass et al. 2011; American Cancer Society 2015b].

The International Agency for Research on Cancer (IARC) has classified alcoholic beverages of all types, in utero exposure to diethylstilbestrol, estrogen-progesterone oral contraceptives and hormone replacement therapy, and exposure to x-rays and gamma rays (types of ionizing 
radiation) as "carcinogenic to humans" with regard to breast cancer [Weiderpass et al. 2011]. The risk from ionizing radiation is highest if exposure occurs during childhood and is negligible if exposure occurs after age 40. IARC states that the studies of an association between female breast cancer and extremely low frequency radiation (which is nonionizing) do not support an association, and that the evidence is sufficient to "give confidence that magnetic fields do not cause" breast cancer [WHO 2007]. Other studies have reached similar conclusions [Feychting and Forssen 2006; Kheifets et al. 2009]. IARC classifies estrogen hormone replacement therapy, smoking, and shift work as "probably carcinogenic to humans" [Weiderpass et al. 2011].

Several studies have found teachers and other professional and managerial employees to have an increased risk for developing breast cancer [Rubin et al. 1993; King et al. 1994; Pollán and Gustavsson 1999; Bernstein et al. 2002; Snedeker 2006; MacArthur et al. 2007], but others have not [Coogan et al. 1996; Calle et al. 1998; Petralia et al. 1998]. No causative workplace exposures have been identified for these occupations, and it is postulated that the possible increase in risk is a result of non-occupational risk factors such as parity (number of times a woman has given birth), maternal age at first birth, contraceptive use, diet, and physical activity [Threlfall et al. 1985; Snedeker 2006; MacArthur et al. 2007]. Women with higher educational status are also more likely to have mammograms, thus increasing detection of breast cancer. Several studies have found that about one quarter to one third of invasive breast cancers detected by mammograms were overdiagnosed, i.e., would not have progressed or caused harm [Zahl et al. 2008; Jørgensen and Gøtzsche 2009; Miller et al. 2014].

\section{Cancer Clusters}

Cancers often appear to occur in clusters, which scientists define as a greater than expected number of cancer cases that occurs within a group of people in a geographic area over a defined period of time [CDC 2012]. A cluster also occurs when the cancers are found among employees of a different age group or sex than is usual. A statistically significant excess of cancer cases may have a common cause, but can occur without a clear cause and can occur by chance [Aldrich and Sinks 2002; Thun and Sinks 2004]. In many workplaces the number of cases is small. This makes detecting whether the cases have a common cause difficult, especially when no apparent cancer-causing exposures are present. It is common for the borders of the "cluster" to be drawn around where the cases of cancer are located, instead of defining the population and geographic area first. This often leads to "clusters" that are not real. This is referred to as the "Texas sharpshooter effect" because the Texas sharpshooter shoots at the barn and then draws his bull's eye around the bullet hole.

When cancer in a workplace is described, learning whether the type of cancer is a primary cancer or a metastasis (spread of the primary cancer into other organs) is important. Only primary cancers are used to investigate a cancer cluster. To assess whether the cancers among employees could be related to occupational exposures, we consider the number of cancer cases, the types of cancer, the likelihood of exposures to potential cancer-causing agents, and the timing of the diagnosis of cancer in relation to the exposure. These issues are discussed below in a series of questions that relate to this request. 


\section{Do school employees have more cancer than people who do not work in the school?}

No. Because cancer is a common disease, cancer may be found among people at any workplace. When several cases of cancer occur in a workplace they may be part of a true cluster when the number is greater than we expect compared to other groups of people similar in age, sex, and race. Disease or tumor rates, however, are highly variable in small populations and rarely match the overall rate for a larger area, such as the state, so that for any given time period some populations have rates above the overall rate and others have rates below the overall rate. Even when a higher rate occurs it may be consistent with the expected random variability. In addition, calculations like this make many assumptions that may not be appropriate for every workplace. Comparing rates without adjusting for age, sex, or other population characteristics assumes that such characteristics are the same in the workplace as in the larger population, which may not be true. However, general information on cancer rates is useful for providing perspective on the cancers in your population. The occurrence of 10 cases of cancer among over 100 employees over several years is not excessive. It is likely that many more current and former employees have been diagnosed with cancer than those who were reported to us, but the numbers and types of the reported cancers do not suggest a need for further case finding. As employees age, more cases of cancer (of many types) will appear.

\section{Do school employees have an unusual distribution of types of cancer?}

No. Cancer clusters thought to be related to a workplace exposure usually consist of the same types of cancer. When several cases of the same type of cancer occur and that type is not common in the general population, it is more likely that an occupational exposure is involved. When the cluster consists of multiple types of cancer, without one type predominating, then an occupational cause of the cluster is less likely.

\section{Is exposure to a specific chemical or physical agent known or suspected of causing cancer or other health effects occurring in the school?}

No. The relationship between some agents and certain cancers has been well established. For other agents and cancers, there is a suspicion of a link but the evidence is not definitive. When a known or suspected cancer-causing agent is present and the types of cancer occurring have been linked with these exposures in other settings, we are more likely to make the connection between cancer and a workplace exposure. School buildings rarely have significant hazardous exposures. There are no exposures known or suspected of causing the reported cancers in the school employees in in the school. Asbestos can be a concern in older buildings, but it is known to cause lung cancer and mesothelioma, not breast or prostate cancer. Asbestos exposure in buildings is typically very low, and usually only relevant to maintenance employees. Exposures to occupants of buildings containing asbestos would typically be minimal. Radon causes lung cancer, not other types of cancer, and radon levels in the school were well below the EPA action level of 4.0 picocuries per liter of air. 
Several employees reported machinery exhaust entering the school. IARC classifies diesel exhaust as Group 1, carcinogenic to humans based on an increased risk for lung cancer [International Agency for Research on Cancer 2012]. No employees were reported to have lung cancer.

\section{Has enough time passed since exposure began?}

This issue is not relevant when considering cancer in this school because there is not an excess of cancer among school employees, the distribution of cancers is not unusual, and no exposures in the school were associated with the cancers diagnosed. Latency is the time between first exposure to a cancer-causing agent and clinical recognition of the disease. Latency periods vary by cancer type but usually are a minimum of 10-12 years [Rugo 2004].

\section{Cancer Prevention}

Employees can take an active role in changing personal risk factors associated with certain types of cancer. The American Cancer Society estimates that about 171,000 cancer deaths in 2015 will be caused by tobacco use alone [American Cancer Society 2015a]. This is one third of all cancer deaths. It is well known that tobacco use increases the risk of cancer of the lung, mouth, nasal cavities, larynx, pharynx, esophagus, stomach, colorectum, liver, pancreas, kidney, bladder, uterine cervix, and ovary (mucinous), and myeloid leukemia [American Cancer Society 2015a]. There is limited evidence that tobacco smoking causes female breast cancer.

Another one quarter to one third of cancer deaths are due to poor nutrition, physical inactivity, overweight, and obesity [American Cancer Society 2015a]. Being overweight or obese is clearly associated with increased risk for developing cancer of the breast (in postmenopausal women), colon and rectum, endometrium, kidney, and pancreas, and adenocarcinoma of the esophagus. Obesity increases the risk of gallbladder cancer and possibly cancers of the liver, cervix, and ovary; multiple myeloma; non-Hodgkin lymphoma; and aggressive forms of prostate cancer [American Cancer Society 2015a].

Alcohol consumption is another modifiable personal risk factor that increases risk of cancer, in addition to the almost two thirds of cancer due to smoking, poor nutrition, physical inactivity, overweight, and obesity. Alcohol causes cancers of the mouth, pharynx, larynx, esophagus, liver colorectum, and breast [American Cancer Society 2015a]. Even a few drinks weekly increase the risk of breast cancer.

The American Cancer Society posts general information about cancer on its website at http:// www.cancer.org/ "Learn About Cancer." For information about a specific type of cancer, click on "Select a Cancer Type," select a type of cancer, then click "Go." Additionally, NIOSH posts information about occupational cancer and cancer cluster evaluations on its website at http://www.cdc.gov/niosh/topics/cancer/.

CDC has a brochure on cancer and chemical exposures titled "Chemicals, Cancer, and You" at http://www.atsdr.cdc.gov/emes/public/docs/Chemicals, \%20Cancer, \%20and\%20You\%20 FS.pdf. It would be useful to share this brochure with all of the employees. 


\section{References}

Agence de la santé et des services sociaux de Montréal [2015]. Evaluation by international experts of the methods used by the Direction de santé publique to assess the health impacts of water damaged buildings. Proceedings of the audit held in April 2013.

Ahn J, Kim D, Kim H, Jahng KY [2010]. Quantitative determination of mycotoxins in urine by LC-MS/MS. Food Addit Contam Part A Chem Anal Control Expo Risk Assess 27(12):1674-1682.

Aldrich T, Sinks T [2002]. Things to know and do about cancer clusters. Cancer Invest 20(5-6):810-816.

American Cancer Society [2015a]. Cancer prevention and early detection facts \& figures 2015 . Atlanta, GA: American Cancer Society. [http://www.cancer.org/acs/groups/content/@editorial/ documents/document/acspc-044552.pdf]. Date accessed: June 2015.

American Cancer Society [2015b]. Detailed guide: breast cancer. Atlanta, GA: American Cancer Society. [http://www.cancer.org/cancer/breastcancer/detailedguide/]. Date accessed: June 2015.

ANSI/ASHRAE [2013a]. Ventilation for acceptable indoor air quality. American National Standards Institute/ASHRAE standard 62.1-2013. Atlanta, GA: American Society of Heating, Refrigerating, and Air-Conditioning Engineers, Inc.

ANSI/ASHRAE [2013b]. Thermal environmental conditions for human occupancy. American National Standards Institute/ASHRAE standard 55-2013. Atlanta, GA: American Society for Heating, Refrigerating, and Air-Conditioning Engineers, Inc.

Aurora R, Chatterjee D, Hentzleman J, Prasad G, Sindwani R, Sanford T [2013]. Contrasting the microbiomes from healthy volunteers and patients with chronic rhinosinusitis. JAMA Otolaryngol Head Neck Surg 139(12):1328-1338. doi: 10.1001/jamaoto.2013.5465.

Barsky AJ, Borus JF [1995]. Somatization and medicalization in the era of managed care. JAMA 274(24):1931-1934.

Benninger MS, Ferguson BJ, Hadley JA, Hamilos DL, Jacobs M, Kennedy DW, Lanza DC, Marple BF, Osguthorpe JD, Stankiewicz JA, Anon J, Denneny J, Emanuel I, Levine H [2003]. Adult chronic rhinosinusitis: definitions, diagnosis, epidemiology, and pathophysiology. Otolayngol Head Neck Surg 129(Suppl 3):S1-S32.

Bernstein L, Allen M, Anton-Culver H, Deapen D, Horn-Ross PL, Peel D, Pinder R, Reynolds P, Sullivan-Halley J, West D, Wright W, Ziogas A, Ross RK [2002]. High breast cancer incidence rates among California teachers: results from the California Teachers Study (United States). Cancer Causes Control 13(7):625-635.

Bogaerts K, Van Eylen L, Li W, Bresseleers J, Van Diest I, De Peuter S, Stans L, Decramer M, Van den Bergh O [2010]. Distorted symptom perception in patients with medically unexplained symptoms. J Abnorm Psychol 119(1):226-234. 
Brightman HS, Milton DK, Wypij D, Burge HA, Spengler JD [2008]. Evaluating buildingrelated symptoms using the US EPA BASE study results. Indoor Air 18(4):335-345.

Calle EE, Murphy TK, Rodriguez C, Thun MJ, Heath CW [1998]. Occupation and breast cancer mortality in a prospective cohort of US women. Am J Epidemiol 148(2):191-197.

CDC (Centers for Disease Control and Prevention) [2012]. Cancer clusters. Atlanta, GA: U.S. Department of Health and Human Services. [http://www.cdc.gov/nceh/clusters/about.

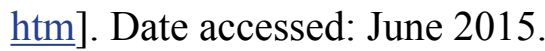

CDC (Centers for Disease Control and Prevention) [2014]. Summary health statistics for U.S. Adults: National Health Interview Survey, 2012. [http://www.cdc.gov/nchs/data/series/ sr_10/sr10_260.pdf]. Date accessed: June 2015.

CFR. Code of Federal Regulations. Washington, DC: U.S. Government Printing Office, Office of the Federal Register.

Cleland EJ, Bassiouni A, Boase S, Dowd S, Vreugde S, Wormald PJ [2014]. The fungal microbiome in chronic rhinosinusitis: richness, diversity, postoperative changes and patient outcomes. Int Forum Allergy Rhinol 4(4):259-265. doi: 10.1002/alr.21297. Epub 2014 Feb 5.

Coogan PF, Clapp RW, Newcomb PA, Mittendorf R, Bogdan G, Baron JA, Longnecker MP [1996]. Variation in female breast cancer risk by occupation. Am J Ind Med 30(4):430-437.

Duarte SC, Pena A, Lino CM [2011]. Human ochratoxin a biomarkers-from exposure to effect. Crit Rev Toxicol 41(3):187-212.

Feychting M, Forssen U [2006]. Electromagnetic fields and female breast cancer. Cancer Causes Control 17(4):553-558.

Fisk WJ, Mirer AG, Mendell MJ [2009]. Quantitative relationship of sick building syndrome symptoms with ventilation rates. Indoor Air 19(2):159-165.

Hamilos DL [2010]. Allergic fungal rhinitis and rhinosinusitis. Proc Am Thor Soc 7(3):245-252.

Heyworth J, McCaul K [2001]. Prevalence of non-specific health symptoms in South Australia. Int J Environ Health Res 11(4):291-298.

International Agency for Research on Cancer [2012]. IARC working group on the evaluation of carcinogenic risks to humans. Diesel and gasoline engine exhausts and some nitroarenes. IARC Monogr Carcinog Risks Hum 105:39-184.

Jørgensen KJ, Gøtzsche PC [2009]. Overdiagnosis in publicly organized mammography screening programs: systematic review of incidence trends. BMJ 339:b2587. doi: 10.1136/bmj.b2587.

Kawamoto M, Page E [2015]. Notes from the field: use of unvalidated urine mycotoxin tests for the clinical diagnosis of illness — United States, 2014. MMWR 64(6):157-158.

Kheifets L, Bowman JD, Checkoway H, Feychting M, Harrington M, Kavet R, Marsh G, Mezei G, Renew DC, van Wijngaarden E [2009]. Future needs of occupational epidemiology 
of extremely low frequency (ELF) electric and magnetic fields (EMF): review and recommendations. Occup Environ Med 66(2):72-80.

King AS, Threlfall WJ, Band PR, Gallagher RP [1994]. Mortality among female registered nurses and school teachers in British Columbia. Am J Ind Med 26(1):125-132.

Lees-Haley PR, Brown RS [1992]. Bias in perception and reporting following a perceived toxic exposure. Percept Mot Skills 75(2):531-544.

MacArthur AC, Le ND, Abanto ZU, Gallagher RP [2007]. Occupational female breast and reproductive cancer mortality in British Columbia, Canada, 1950-1994. Occup Med 57(4):246-253.

Malkin R, Wilcox T, Sieber WK [1996]. The National Institute for Occupational Safety and Health indoor environmental evaluation experience. Part two: symptom prevalence. Appl Occup Environ Hyg 11(6):540-545.

McAteer A, Elliott AM, Hannaford PC [2011]. Ascertaining the size of the symptom iceberg in a UK-wide community-based survey. Br J Gen Pract 61(582):e1-11. doi: 10.3399/ bjgp11X548910.

Mendell MJ, Eliseeva EA, Davies MM, Spears M, Lobscheid A, Fisk WJ, Apte MG [2013]. Association of classroom ventilation with reduced illness absence: a prospective study in California elementary schools. Indoor Air 23(6):515-528. doi: 10.1111/ina.12042.

Mendell MJ, Mirer AG, Cheung K, Tong M, Douwes J [2011]. Respiratory and allergic health effects of dampness, mold, and dampness-related agents: a review of the epidemiologic evidence. Environ Health Perspect 119(6):748-756. doi: 10.1289/ehp.1002410.

Miller AB, Wall C, Baines CJ, Sun P, To T, Narod SA [2014]. Twenty five year follow-up for breast cancer incidence and mortality of the Canadian national breast screening study: randomized screening trial. BMJ 348:g366. doi: 10.1136/bmj.g366.

Milton DK, Glencross PM, Walters MD [2000]. Risk of sick leave associated with outdoor air supply rate, humidification, and occupant complaints. Indoor Air 10(4):212-221.

NIOSH [2012]. NIOSH alert: preventing occupational respiratory disease from exposures caused by dampness in office buildings, schools, and other nonindustrial buildings.

Cincinnati, OH: U.S. Department of Health and Human Services, Centers for Disease Control and Prevention, National Institute for Occupational Safety and Health, DHHS (NIOSH) Publication No. 2013-102.

Petralia SA, Vena JE, Freudenheim JL, Marshall JR, Michalek A, Brasure J, Swanson M, Graham S [1998]. Breast cancer risk and lifetime occupational history: employment in professional and managerial occupations. Occup Environ Med 55(1):43-48.

Petrie KJ, Faasse K, Crichton F, Grey A [2014]. How common are symptoms? Evidence from a New Zealand national telephone survey. BMJ Open. 4(6):e005374. doi: 10.1136/ bmjopen-2014-005374. 
Pollán M, Gustavsson P [1999]. High-risk occupations for breast cancer in the Swedish female working population. Am J Public Health 89(6):875-881.

Rubin CH, Burnett CA, Halperin WE, Seligman PJ [1993]. Occupation as a risk identifier for breast cancer. Am J Public Health 83(9):1311-1315.

Rugo H [2004]. Occupational cancer. In: LaDou J, ed. Current occupational and environmental medicine. New York: McGraw Hill Companies, Inc., pp. 229-267.

Shendell DG, Prill R, Fisk WJ, Apte MG, Blake D, Faulkner D [2004]. Associations between classroom $\mathrm{CO} 2$ concentrations and student attendance in Washington and Idaho. Indoor Air 14(5):333-341.

Snedeker SM [2006]. Chemical exposures in the workplace: effect on breast cancer risk among women. AAOHN J 54(6):270-279.

The Human Microbiome Project Consortium [2012]. Structure, function and diversity of the healthy human microbiome. Nature 486(7402):207-214. doi: 10.1038/nature11234.

Threlfall WJ, Gallagher RP, Spinelli JJ, Band PR [1985]. Reproductive variables as possible confounders in occupational studies of breast and ovarian cancer in females. J Occup Med 27(6):448-450.

Thun MJ, Sinks T [2004]. Understanding cancer clusters. CA Cancer J Clin 54(5):273-290.

Trout DB, Seltzer JM, Page EH, Biagini RE, Schmechel D, Lewis DM, Boudreau AY [2004]. Clinical use of immunoassays in assessing exposure to fungi and potential health effects related to fungal exposure. Ann Allergy Asthma Immunol 92(5):483-491.

Watson D, Pennebaker JW [1989]. Health complaints, stress, and distress: exploring the central role of negative affectivity. Psychol Rev 96(2):234-254.

WHO [2007]. Extremely low frequency fields. Environmental health criteria 238. Geneva, Switzerland: World Health Organization. [http://www.who.int/peh-emf/publications/ Complet_DEC_2007.pdf]. Date accessed: June 2015.

WHO [2009]. WHO guidelines for indoor air quality: dampness and mould. Geneva, Switzerland: World Health Organization. [http://www.euro.who.int/document/e92645.pdf].

Date accessed: June 2015.

Weiderpass E, Meo M, Vainio H [2011]. Risk factors for breast cancer, including occupational exposures. Saf Health Work 2(1):1-8.

Williams CW, Lees-Haley PR [1993]. Perceived toxic exposure: a review of four cognitive influences on perception of illness. J Soc Behav Pers 8(3):489-506.

Zahl PH, Maehlen J, Welch HG [2008]. The natural history of invasive breast cancers detected by screening mammography. Arch Intern Med 168(21):2311-2316. 
Keywords: North American Industry Classification System 611110 (Elementary and Secondary Schools), New York, mold, crawl space, indoor environmental quality, IEQ, ventilation, immunoglobulin $\mathrm{G}$, mycotoxin 
The Health Hazard Evaluation Program investigates possible health hazards in the workplace under the authority of the Occupational Safety and Health Act of 1970 (29 U.S.C. § 669(a) (6)). The Health Hazard Evaluation Program also provides, upon request, technical assistance to federal, state, and local agencies to investigate occupational health hazards and to prevent occupational disease or injury. Regulations guiding the Program can be found in Title 42, Code of Federal Regulations, Part 85; Requests for Health Hazard Evaluations (42 CFR Part 85).

\section{Disclaimer}

The recommendations in this report are made on the basis of the findings at the workplace evaluated and may not be applicable to other workplaces.

Mention of any company or product in this report does not constitute endorsement by NIOSH.

Citations to Web sites external to NIOSH do not constitute NIOSH endorsement of the sponsoring organizations or their programs or products. NIOSH is not responsible for the content of these Web sites. All Web addresses referenced in this document were accessible as of the publication date.

\section{Acknowledgments}

Desktop Publishers: Shawna Watts

Editor: Ellen Galloway

Logistics: Donnie Booher, Kevin Moore

Medical Field Assistance: Sadie Sanchez

\section{Availability of Report}

Copies of this report have been sent to the employer, employees, and union at the facility. The state and local health department and the Occupational Safety and Health Administration Regional Office have also received a copy. This report is not copyrighted and may be freely reproduced.

This report is available at http://www.cdc.gov/niosh/hhe/reports/pdfs/2015-0025-3237.pdf.

\section{Recommended citation for this report:}

NIOSH [2015]. Health hazard evaluation report: evaluation of indoor environmental quality and health concerns in a public elementary school. By Page E, Burr G, Zwack L, Kawamoto M. Cincinnati, OH: U.S. Department of Health and Human Services, Centers for Disease Control and Prevention, National Institute for Occupational Safety and Health, NIOSH HHE Report No. 2015-0025-3237. 
Delivering on the Nation's promise:

Safety and health at work for all people through research and prevention

To receive NIOSH documents or more information about occupational safety and health topics, please contact NIOSH:

Telephone: 1-800-CDC-INFO (1-800-232-4636)

TTY: 1-888-232-6348

CDC INFO: www.cdc.gov/info

or visit the NIOSH Web site at www.cdc.gov/niosh

For a monthly update on news at $\mathrm{NIOSH}$, subscribe to

$\mathrm{NIOSH}$ eNews by visiting www.cdc.gov/niosh/eNews. 